\title{
Safety Evaluation of Potential Toxic Metals Exposure from Street Foods Consumed in Mid-West Nigeria
}

\author{
O. C. Ekhator, ${ }^{1}$ N. A. Udowelle, ${ }^{1}$ S. Igbiri, ${ }^{1}$ R. N. Asomugha, ${ }^{2}$ \\ Z. N. Igweze, ${ }^{3}$ and O. E. Orisakwe ${ }^{1}$ \\ ${ }^{1}$ Department of Experimental Pharmacology \& Toxicology, Faculty of Pharmacy, University of Port Harcourt, Rivers State, Nigeria \\ ${ }^{2}$ Department of Chemistry, Faculty of Science, Nnamdi Azikiwe University, Awka, Anambra State, Nigeria \\ ${ }^{3}$ Faculty of Pharmacy, Madonna University Elele, Port Harcourt, Rivers State, Nigeria
}

Correspondence should be addressed to O. E. Orisakwe; orishebere@gmail.com

Received 24 December 2016; Revised 9 March 2017; Accepted 5 April 2017; Published 26 April 2017

Academic Editor: Brian Buckley

Copyright (C) 2017 O. C. Ekhator et al. This is an open access article distributed under the Creative Commons Attribution License, which permits unrestricted use, distribution, and reproduction in any medium, provided the original work is properly cited.

\begin{abstract}
Objective. Street-vended foods offer numerous advantages to food security; nevertheless, the safety of street food should be considered. This study has investigated the level of potential toxic metal ( $\mathrm{Pb}, \mathrm{Cd}, \mathrm{Hg}, \mathrm{Sb}, \mathrm{Mn}$, and $\mathrm{Al}$ ) contamination among streetvended foods in Benin City and Umunede. Methods. Twenty street food samples were purchased from vendors at bus stops. Metals were analyzed with atomic absorption spectrophotometry. The methods developed by the US EPA were employed to evaluate the potential health risk of toxic metals. Results. The concentrations of the toxic metals in $\mathrm{mg} / \mathrm{kg}$ were in the range of $\mathrm{Pb}(0.014-1.37)$, $\mathrm{Cd}(0.00-0.00017), \mathrm{Hg}(0.00-0.00014)$, Sb (0.00-0.021), Mn (0.00-0.012), and $\mathrm{Al}(0.00-0.22)$. All the toxic metals except $\mathrm{Pb}$ were below permissible limit set by WHO, EU, and USEPA. The daily intake, hazard quotient, and hazard index of all toxic metals except for $\mathrm{Pb}$ in some street foods were below the tolerable daily intake and threshold value of 1 , indicating an insignificant health risk. Total cancer risk was within the priority risk level of $1.0 E-04$ but higher than the acceptable risk level of $1 E-06$. Conclusion. Consumption of some of these street foods is of public health concern.
\end{abstract}

\section{Introduction}

In Nigeria and all over the world, millions of people daily consume street foods that provide a wide range of essential energy needs and nutrients. According to a survey by the World health Organization (WHO) in 1996, 74\% of countries reported that street foods contribute significantly to urban food supply [1], defined as "ready-to-eat foods," processed or fresh, which are sold at stationary locations or hawked in streets and open places as opposed to stores and licensed establishments [2]. These foods are mostly cheap and they are also easily accessible [3-5]. There is a wide acceptability of street-vended foods among majority of the Nigerian population which cuts across social, cultural, and political class. The inexpensive and convenient nature of these hawked foods has experienced an economic boom in the last decade.

Although street food offers numerous advantages in improving food security, the safety of these foods should be properly monitored. Food safety is the assurance that food will not cause any harm or deleterious effect to the consumer when it is consumed [1]. Street foods can pose a possible health risk to habitual consumers because food prepared and exposed to the open air for sale may become contaminated by pathogenic microorganism as well as chemical toxicant [6]. Contamination of street food is as a result of so many factors such as preparation methods, poor packaging, vehicular exhaust emission, indiscriminate waste disposal, poor sanitation, industrial emission, and a list of all other pollution sources in the surrounding vending area [7].

This is possible as vending sites are usually within congested streets characterised by heavy vehicular traffic and industrial or commercial activities.

Recent researches have shown that potential toxic metals are now one of the major food and dietary contaminants in southern Nigeria $[8,9]$. A number of serious health issues can develop as a result of excessive uptake of potential toxic 


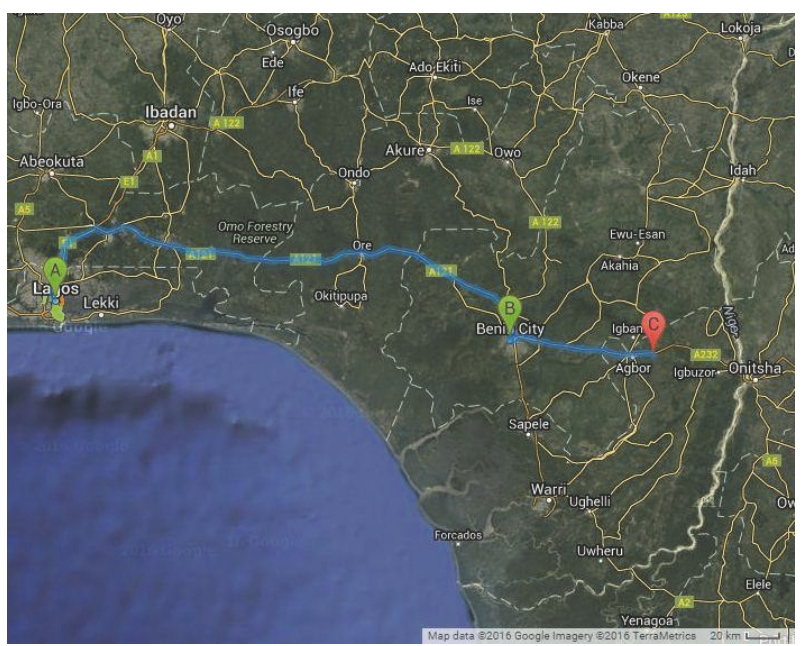

Figure 1: Google map of Nigeria showing Lagos (A), Benin City (B), and Umunede (C), Onitsha highway.

metals such as lead, cadmium, mercury, aluminium, manganese, and antimony from dietary sources. Furthermore, excessive depletion of essential nutrients in the body can occur as a result of consumption of potential toxic metalcontaminated foods, causing a decrease in immunological defences, intrauterine growth retardation, impaired psychosocial behaviors, disabilities associated with malnutrition, and a high prevalence of upper gastrointestinal cancer $[9,10]$.

Continuous ingestion of heavy metals can have a damaging effect on humans and animals $[11,12]$. Heavy metals like chromium, copper, manganese, and zinc reportedly can cause noncarcinogenic hazards such as neurologic disorders and liver disease when they are present in food in concentrations above their safe levels [13]. Consumption of rice and other foods contaminated with cadmium were associated with an increased risk of menopausal breast cancer [14]. Heavy metals induced toxicity is of public health concern, since food ingestion is the major pathway for human exposure to toxic substances. Therefore, there is the need to monitor their levels in frequently consumed street foods marketed in Nigerian cities. This study is aimed at investigating the levels of potential toxic metals $(\mathrm{Pb}, \mathrm{Cd}, \mathrm{Hg}, \mathrm{Sb}, \mathrm{Mn}$, and $\mathrm{Al})$ and also calculating the dietary daily intake as well as the hazard quotient and cancer risk in street foods commonly consumed in Benin City and Umunede, Nigeria, to assess their health risk.

\section{Materials and Methods}

2.1. Collection of Samples. In February 2016, twenty different varieties of commonly consumed street food samples such as jollof rice, spaghetti, beans, roasted plantain, fried chicken, fried turkey, fried meat, fried fish, doughnut, meat pie, edible maggot, roasted yam, buns, fried plantain, white rice, stewed meat, salad, cake, sausage, and moi-moi were purchased from major bus stops at different locations in Benin City and Umunede, Mid-Western Nigeria (Figure 1), directly from the vendors. The food samples were collected in glass Petri dish.
Three samples of a particular variety were collected from the different locations. The foods were cut into small pieces and kept in tightly sealed glass Petri dish in the refrigerator for subsequent ashing, digestion, and analysis.

\subsection{Determination of Potential Toxic Metals}

2.2.1. Digestion of Samples. Five grams of each food sample was digested in $9 \mathrm{~mL}$ of $65 \%$ concentrated $\mathrm{HNO}_{3}$ and $3 \mathrm{~mL}$ perchloric acid. The solution was transferred to a hot plate of $110^{\circ} \mathrm{C}$ for about 5 hours. Afterwards, the samples were introduced into an oven under a temperature that was gradually increased in $100^{\circ} \mathrm{C}$ every 60 minutes until the wished final temperature of $450^{\circ} \mathrm{C}$ was reached 18 hours later; white ashes were obtained. Following this, samples were left to cool. The white ashes were then dissolved with $1.5 \% \mathrm{HNO}_{3}$ $(5 \mathrm{~mL})$ and a final volume of $25 \mathrm{~mL}$ was made by adding deionized water. The resulting solution was filtered using a Whatman filter paper (number 42) fitted into a Bucher funnel into a beaker before it was transferred into a tightly sealed plastic container.

2.3. Analysis. The presence of $\mathrm{Pb}, \mathrm{Cd}, \mathrm{Hg}, \mathrm{Sb}, \mathrm{Mn}$, and $\mathrm{Al}$ was analyzed in samples using a Solaar Thermo Elemental Flame Absorption Spectrometer (S4 710).

2.4. Quality Control. The instrument was recalibrated after every ten runs. The analytical procedure was checked using spike recovery method (SRM). A known standard of the metals was introduced into already analyzed samples and reanalyzed. The results of the recovery studies for $\mathrm{Pb}, \mathrm{Cd}, \mathrm{Hg}$, $\mathrm{Sb}, \mathrm{Mn}$, and $\mathrm{Al}$ were more than $95 \%$. The relative standard deviation between replicate analyses was less than $4 \%$. The limit of detection (LOD) for $\mathrm{Cd}, \mathrm{Hg}, \mathrm{Sb}, \mathrm{Mn}$, and $\mathrm{Al}$ was 0.005 whereas the $\mathrm{LOD}$ of $\mathrm{Pb}$ was $0.01 \mathrm{ppm}$, with blank values reading as $0.00 \mathrm{ppm}$ for all the metals in deionized water with electrical conductivity value of lower than $5 \mu \mathrm{S} / \mathrm{cm}$. The limits of quantification LOQ for Cd and Sb were 0.004 and for $\mathrm{Hg}, \mathrm{Mn}$, and $\mathrm{Al}$ were $0.006 \mathrm{ppm}$. Two-way analysis of variance (ANOVA) and a Student's $t$-test were used to determine whether the concentrations of the metals varied significantly, with values less than $0.05(p<0.05)$ considered to be statistically significant. The statistical calculations were performed with Graph Pad Prism 5.0.

\section{Risk Assessment Methods}

The human health risk models including carcinogenic and noncarcinogenic developed by US EPA have proved successful and been adopted worldwide. Currently, there is no agreed limit for acceptable maximum carcinogenic and noncarcinogenic risk levels in Nigeria. We therefore employed the US EPA model and its threshold values to assess the potential human health risks posed by heavy metal contamination in this study.

3.1. Estimated Daily Intake. The daily intake of metals depends on the metal concentration in food, the daily food 
consumption, and the body weight. The estimated daily intake (EDI) of metals is a concept introduced to take into account these factors. The EDI was calculated based on the following formula [15]:

$$
\mathrm{EDI}=\frac{C_{\text {metal }} \times D_{\text {food intake }}}{\mathrm{BW}_{\text {average }}},
$$

where $C$ is the metal concentration in the street food in $\mathrm{mg} / \mathrm{kg}, D$ is the daily intake of food in $\mathrm{kg}_{\text {person }}{ }^{-1}$, and BW is average body weight in $\mathrm{kg}$ (70 kg adults, $24 \mathrm{~kg}$ children).

\subsection{Noncarcinogenic Risk}

3.2.1. Target Hazard Quotient (THQ). Noncarcinogenic risk estimation of heavy metals consumption was determined using THQ values. THQ is a ratio of the determined dose of a pollutant to a reference level considered harmful. THQ values were determined based on the following formula [15]:

$$
\mathrm{THQ}=\frac{\mathrm{Efr} \times \mathrm{ED} \times \mathrm{FIR} \times \mathrm{C}}{\mathrm{RfDo} \times \mathrm{B}_{\text {average wt }} \times \mathrm{ATn} \times 10^{-3}},
$$

where Efr is exposure frequency assumed to be 365 days year $^{-1}, \mathrm{ED}$ is exposure duration in 56 years equivalent to an average lifetime, FIR is average daily consumption in $\mathrm{kg}$ person $^{-1}$ day $^{-1}, C$ is concentration of metal in food sample in $\mathrm{mg} / \mathrm{kg}, \mathrm{RfDo}$ is reference dose in $\mathrm{mg} / \mathrm{kg} \mathrm{day}^{-1}$, and ATn is average exposure time for noncarcinogens in days.

3.2.2. Chronic Hazard Index (HI). The chronic hazard index (HI) is the sum of more than one hazard quotient for multiple toxicants or multiple exposure pathways; it was calculated using the equation below:

$$
\mathrm{HI}=\sum \mathrm{THQ}
$$

3.3. Carcinogenic Risk. Cancer risk can be evaluated from

$$
\text { Cancer risk }=\mathrm{CDI} \times \mathrm{SF} \text {, }
$$

where cancer risk represents the probability of an individual lifetime health risks from carcinogens; CDI is the chronic daily intake of carcinogens $\left(\mathrm{mg} \mathrm{kg}^{-1} \mathrm{~d}^{-1}\right)$; $\mathrm{SF}$ is the slope factor of hazardous substances $\left(\mathrm{mg} \mathrm{kg}^{-1} \mathrm{~d}^{-1}\right)$.

The cumulative cancer risk can be calculated from

$$
\text { Total cancer risk }=\sum_{k=1}^{n} \mathrm{CDI}_{k} \mathrm{SF}_{k} \text {, }
$$

where $\mathrm{CDI}_{k}$ is the chronic daily intake $\left(\mathrm{mg} \mathrm{kg}^{-1} \mathrm{~d}^{-1}\right)$; of substance $k, \mathrm{SF}_{k}$ is the slope factor for substance $k\left(\mathrm{mg} \mathrm{kg}^{-1} \mathrm{~d}^{-1}\right)$. The acceptable or tolerable risk for regulatory purposes is within the range of $10^{-6}-10^{-4}[16]$.

\section{Results}

Table 1 shows the level of potential toxic metals $(\mathrm{Pb}, \mathrm{Cd}$, $\mathrm{Hg}, \mathrm{Sb}, \mathrm{Mn}$, and $\mathrm{Al}$ ) in street foods: jollof rice, spaghetti, beans, roasted plantain, fried chicken, fried turkey, fried meat, fried fish, doughnut, meat pie, edible maggot, roasted yam, buns, fried plantain, white rice, stewed meat, salad, cake, sausage, and moi-moi. The concentration $(\mathrm{mg} / \mathrm{kg})$ of the various metals in the street food samples ranged within $0.00-1.37 \mathrm{mg} / \mathrm{kg}$ in $\mathrm{Pb}(0.014-1.37), \mathrm{Cd}(0.00-0.0017), \mathrm{Hg}$ (0.00-0.0014), Sb (0.00-0.021), Mn (0.00-0.012), and AI (0.00-0.225) all in $\mathrm{mg} / \mathrm{kg}$, respectively. The highest levels of heavy metals concentration were detected in $\mathrm{Pb}$ (beans, $1.37 \mathrm{mg} / \mathrm{kg}$ ), Cd (stewed meat, 0.0017), Hg (stewed meat, 0.0014), Sb (fried fish, 0.021), Mn (fried meat, 0.012), and AI (stewed meat, $0.221 \mathrm{mg} / \mathrm{kg}$ ), respectively. $\mathrm{Pb}$ was detected in $100 \%$ of the investigated street food samples, $70 \%$ of the street food samples showed Cd levels which were below the limit of detection $(<0.001)$, and also $80 \%$ of the studied samples had $\mathrm{Hg}$ levels which were below the detectable limit. $\mathrm{Mn}$ and $\mathrm{Al}$ were observed to be below the detectable limit in $65 \%$ and $10 \%$ of street food samples, respectively.

Table 2 shows the estimated daily intake (EDI) of heavy metals for an individual with a body weight of $70 \mathrm{~kg}$ and $24 \mathrm{~kg}$ for adults and children, respectively. The daily intake of $\mathrm{Pb}$ from street food consumption for both adults and children ranged within $0.00004-0.0069$ and $0.000072-0.011 \mathrm{mg} / \mathrm{kg}$ bw day $^{-1}$, respectively. The highest intake of $\mathrm{Pb}$ was from beans consumption with a daily intake of 0.0069 and $0.011 \mathrm{mg} / \mathrm{kg}$ bw day ${ }^{-1}$ for adults and children, respectively. The estimated daily intake of $\mathrm{Cd}$ from street food for adults and children ranged within $1.30 E-6-4.50 E-6$ and $2.2 E-6-9.9 E-6 \mathrm{mg} / \mathrm{kg}$ bw day ${ }^{-1}$, respectively. The stewed meat had the highest daily intake of cadmium with a daily intake rate of $4.50 E-6$ and $9.90 E-6$ for adults and children, respectively. Daily intake rate of $\mathrm{Hg}$ ranged within $2.60 E-7-3.70 E-6$ and $5.80 E-7-8.17 E-6$ for adults and children. Stewed meat with an intake rate of $3.7 E-6$ and $8.17 E-6$ for both adults and children contributed the highest daily intake of $\mathrm{Hg}$. Also the consumption of fried meat and white rice with an EDI of $5.70 E-6$ was observed to be the source for highest intake of $\mathrm{Sb}$ in adults while the highest intake of $\mathrm{Sb}$ for children was seen in fried meat $(1.20 E-4)$. The EDI of $\mathrm{Mn}$ from street food samples ranged within $9.2 E-6-5.7 E-4 \mathrm{mg} / \mathrm{kg}$ bw/day in adults and $1.3 E-5-1.3 E-3 \mathrm{mg} / \mathrm{kg}$ bw/day in children; the highest value was found in stewed meat for both adults and children with intake values of $5.7 E-4$ and $1.3 E-3 \mathrm{mg} / \mathrm{kg}$ bw/day, respectively. Table 2 shows the estimated daily intake (EDI) of heavy metals for an individual with a body weight of $70 \mathrm{~kg}$ and $24 \mathrm{~kg}$ for adult and children, respectively. The daily intake of $\mathrm{Pb}$ from street food consumption for both adults and children ranged within 0.00004-0.0069 and $0.000072-0.011 \mathrm{mg} / \mathrm{kg}$ bw $\mathrm{day}^{-1}$, respectively. The highest intake of $\mathrm{Pb}$ was from beans consumption with a daily intake of 0.0069 and $0.011 \mathrm{mg} / \mathrm{kg}$ bw day ${ }^{1}$ for adults and children, respectively. The estimated daily intake of $\mathrm{Cd}$ from street food for adult and children ranged within $1.30 E-6-4.50 E-6$ and $2.2 E-6-9.9 E-6 \mathrm{mg} / \mathrm{kg}$ bw day ${ }^{-1}$, respectively. The stewed meat had the highest daily intake of cadmium with a daily intake rate of $4.50 E-6$ and $9.90 E-6$ for adults and children, respectively. Daily intake rate of $\mathrm{Hg}$ ranged within $2.60 E-7-3.70 E-6$ and $5.80 E-7-8.17 E-6$ for adults and 
TABLE 1: Concentration ( $\mathrm{mg} / \mathrm{kg}$ ) of heavy metals in commonly consumed street foods marketed in Benin City and Umunede, Mid-Western Nigeria.

\begin{tabular}{|c|c|c|c|c|c|c|}
\hline Location/samples & $\mathrm{Pb}$ & $\mathrm{Cd}$ & $\mathrm{Hg}$ & $\mathrm{Sb}$ & $\mathrm{Mn}$ & $\mathrm{Al}$ \\
\hline \multicolumn{7}{|l|}{ Benin City } \\
\hline Salad & 0.14 & $<0.001$ & $<0.001$ & $<0.001$ & $<0.001$ & 0.003 \\
\hline Jollof rice & 0.31 & $<0.001$ & $<0.001$ & 0.0013 & $<0.001$ & 0.007 \\
\hline Meat pie & 0.24 & $<0.001$ & $<0.001$ & 0.013 & 0.01 & 0.011 \\
\hline Doughnut & 0.21 & $<0.001$ & $<0.001$ & 0.002 & $<0.001$ & 0.003 \\
\hline Cake & 0.12 & $<0.001$ & $<0.001$ & $<0.001$ & $<0.001$ & $<0.001$ \\
\hline Sausage & 0.14 & $<0.001$ & $<0.001$ & 0.0012 & $<0.001$ & $<0.001$ \\
\hline Fried meat & 0.31 & 0.0012 & 0.0001 & 0.02 & 0.012 & 0.034 \\
\hline Fried chicken & 0.026 & 0.0013 & $<0.001$ & 0.012 & 0.0019 & 0.012 \\
\hline Fried turkey & 0.14 & 0.001 & 0.0003 & 0.0114 & 0.0011 & 0.024 \\
\hline Edible maggot & 0.014 & 0.0011 & $<0.001$ & 0.0029 & 0.0033 & 0.104 \\
\hline \multicolumn{7}{|l|}{ Umunede } \\
\hline Fried fish & 0.2 & 0.001 & 0.0012 & 0.021 & 0.0032 & 0.135 \\
\hline Stewed meat & 1.34 & 0.0017 & 0.0014 & 0.0021 & 0.0044 & 0.22 \\
\hline Roasted plantain & 0.31 & $<0.001$ & $<0.001$ & 0.0021 & $<0.001$ & 0.017 \\
\hline Roasted yam & 0.13 & $<0.001$ & $<0.001$ & 0.0013 & $<0.001$ & 0.043 \\
\hline Spaghetti & 0.24 & $<0.001$ & $<0.001$ & $<0.001$ & $<0.001$ & 0.013 \\
\hline White rice & 1.033 & $<0.001$ & $<0.001$ & 0.0114 & $<0.001$ & 0.004 \\
\hline Beans & 1.37 & $<0.001$ & $<0.001$ & 0.0014 & $<0.001$ & 0.042 \\
\hline Buns & 0.14 & $<0.001$ & $<0.001$ & $<0.001$ & $<0.001$ & 0.022 \\
\hline Moi-moi & 1.24 & $<0.001$ & $<0.001$ & $<0.001$ & $<0.001$ & 0.0103 \\
\hline Fried plantain & 0.24 & $<0.001$ & $<0.001$ & 0.0023 & $<0.001$ & 0.0114 \\
\hline
\end{tabular}

$<0.001$ : below detectable limit.

TABLE 2: Estimated daily intake of heavy metals ( $\mathrm{mg} / \mathrm{kg}$ bw/day) for adults $(70 \mathrm{~kg})$ and children $(24 \mathrm{~kg})$ from consumption of street-vended foods sold in Benin City and Umunede.

\begin{tabular}{|c|c|c|c|c|c|c|c|c|c|c|c|c|}
\hline \multirow{2}{*}{ Location } & \multicolumn{6}{|c|}{ Adult $70 \mathrm{Kg}$} & \multicolumn{6}{|c|}{ Children $24 \mathrm{~kg}$} \\
\hline & $\mathrm{Pb}$ & $\mathrm{Cd}$ & $\mathrm{Hg}$ & $\mathrm{Sb}$ & $\mathrm{Mn}$ & $\mathrm{Al}$ & $\mathrm{Pb}$ & $\mathrm{Cd}$ & $\mathrm{Hg}$ & $\mathrm{Sb}$ & $\mathrm{Mn}$ & $\mathrm{Al}$ \\
\hline \multicolumn{13}{|l|}{ Benin City } \\
\hline Salad & 0.0005 & ND & ND & ND & ND & $1.0 E-5$ & $7.3 E-4$ & ND & ND & ND & ND & $1.6 E-5$ \\
\hline Jollof rice & 0.0016 & ND & ND & $6.5 E-6$ & ND & $3.6 E-5$ & $2.6 E-3$ & ND & ND & $1.1 E-5$ & $\mathrm{ND}$ & $5.9 E-5$ \\
\hline Meat pie & 0.0007 & ND & ND & $3.5 E-5$ & $2.8 E-5$ & $3.1 E-5$ & $9.6 E-4$ & ND & ND & $5.1 E-5$ & $4.1 E-5$ & $4.5 E-5$ \\
\hline Doughnut & 0.0006 & ND & ND & $6.2 E-6$ & ND & $9.2 E-6$ & $8.3 E-4$ & ND & ND & $9.1 E-6$ & ND & $1.3 E-5$ \\
\hline Cake & 0.0003 & $\mathrm{ND}$ & ND & ND & ND & ND & $4.8 E-4$ & ND & ND & ND & ND & ND \\
\hline Sausage & 0.0004 & ND & ND & $3.3 E-6$ & ND & ND & $5.6 E-4$ & ND & ND & $4.8 E-6$ & $\mathrm{ND}$ & ND \\
\hline Fried meat & 0.0008 & $3.2 E-6$ & $2.6 E-7$ & $5.7 E-5$ & $3.2 E-5$ & $9.0 E-5$ & $1.8 E-3$ & $7 E-6$ & $5.8 E-7$ & $1.2 E-4$ & $7 E-5$ & $2 E-4$ \\
\hline Fried chicken & $7.0 E-5$ & $3.4 E-6$ & ND & $3.2 E-5$ & $5.0 E-6$ & $3.2 E-5$ & $1.5 E-4$ & $7.6 E-6$ & ND & $7.5 E-5$ & $1 E-5$ & $7.1 E-5$ \\
\hline Fried turkey & 0.0004 & $2.6 E-6$ & $7.9 E-7$ & $3.0 E-5$ & $2.9 E-6$ & $6.4 E-5$ & $8.2 E-4$ & $5.8 E-6$ & $1.8 E-6$ & $6.7 E-5$ & $6.4 E-6$ & $1.4 E-4$ \\
\hline Edible maggot & $4.0 E-5$ & $2.9 E-6$ & ND & $7.7 E-6$ & $8.7 E-6$ & $2.7 E-4$ & $7.2 E-5$ & $5.7 E-6$ & ND & $1.5 E-5$ & $1.7 E-5$ & $5.4 E-4$ \\
\hline \multicolumn{13}{|l|}{ Umunede } \\
\hline Fried fish & 0.0003 & $1.3 E-6$ & $1.6 E-6$ & $2.8 E-5$ & $4.2 E-6$ & $1.8 E-4$ & $4.5 E-4$ & $2.2 E-6$ & $2.2 E-6$ & $4.6 E-5$ & $6.9 E-5$ & $2.9 E-4$ \\
\hline Stewed meat & 0.0035 & $4.5 E-6$ & $3.7 E-6$ & $5.6 E-6$ & $1.2 E-5$ & $5.7 E-4$ & $7.8 E-3$ & $9.9 E-6$ & $8.2 E-6$ & $1.2 E-5$ & $2.6 E-5$ & $1.3 E-3$ \\
\hline Roasted plantain & 0.0009 & ND & ND & $6.0 E-6$ & ND & $4.8 E-5$ & $8.3 E-4$ & ND & ND & $5.6 E-6$ & ND & $4.5 E-5$ \\
\hline Roasted yam & 0.0004 & ND & ND & $3.7 E-6$ & ND & $1.2 E-4$ & $3.4 E-4$ & ND & ND & $3.5 E-6$ & ND & $1.1 E-4$ \\
\hline Spaghetti & 0.0012 & ND & ND & ND & ND & $6.5 E-5$ & $2.3 E-3$ & ND & ND & ND & ND & $1.1 E-4$ \\
\hline White rice & 0.0052 & ND & ND & $5.7 E-5$ & ND & $1.9 E-5$ & $8.6 E-3$ & ND & ND & $9.5 E-5$ & ND & $3.1 E-5$ \\
\hline Beans & 0.0069 & ND & ND & $7.0 E-6$ & ND & $2.1 E-4$ & $1.1 E-2$ & ND & ND & $1.2 E-5$ & ND & $3.5 E-4$ \\
\hline Buns & 0.0004 & $\mathrm{ND}$ & ND & ND & ND & $5.9 E-5$ & $5.7 E-4$ & ND & ND & ND & ND & $8.6 E-5$ \\
\hline Moi-moi & 0.0062 & ND & ND & ND & ND & $5.2 E-5$ & $1.0 E-2$ & ND & ND & ND & ND & $8.6 E-5$ \\
\hline Fried plantain & 0.0007 & ND & ND & $6.6 E-6$ & ND & $3.3 E-5$ & $6.3 E-4$ & ND & ND & $6.6 E-6$ & ND & $3.0 E-5$ \\
\hline
\end{tabular}


TABLE 3: Target hazard quotient (THQ) and hazard index (HI) for adults and children exposed to street-vended foods contaminated with heavy metals in Benin City and Umunede, Mid-Western Nigeria.

\begin{tabular}{|c|c|c|c|c|c|c|c|c|c|c|c|c|c|c|}
\hline \multirow{2}{*}{ Samples } & \multicolumn{7}{|c|}{ Adult $70 \mathrm{Kg}$} & \multicolumn{7}{|c|}{ Children $24 \mathrm{Kg}$} \\
\hline & $\mathrm{Pb}$ & $\mathrm{Cd}$ & $\mathrm{Hg}$ & $\mathrm{Sb}$ & $\mathrm{Mn}$ & $\mathrm{Al}$ & HI & $\mathrm{Pb}$ & $\mathrm{Cd}$ & $\mathrm{Hg}$ & $\mathrm{Sb}$ & $\mathrm{Mn}$ & $\mathrm{Al}$ & HI \\
\hline \multicolumn{15}{|l|}{ Benin City } \\
\hline Salad & 0.1139 & ND & ND & ND & ND & $7.1 E-5$ & 0.11 & 0.1837 & ND & ND & ND & ND & 0.0001 & 0.18 \\
\hline Jollof rice & 0.3896 & ND & ND & 0.0163 & ND & $2.5 E-4$ & 0.41 & 0.6526 & ND & ND & 0.0272 & ND & 0.0004 & 0.68 \\
\hline Meat pie & 0.1653 & ND & ND & 0.0882 & 0.002 & $2.2 E-4$ & 0.26 & 0.2411 & ND & ND & 0.1286 & 0.0029 & 0.0003 & 0.37 \\
\hline Doughnut & 0.1426 & ND & ND & 0.0156 & ND & $6.6 E-5$ & 0.16 & 0.2079 & ND & ND & 0.0228 & ND & $1 E-4$ & 0.23 \\
\hline Cake & 0.0823 & ND & ND & ND & ND & ND & 0.08 & 0.12 & ND & ND & ND & ND & ND & 0.12 \\
\hline Sausage & 0.0956 & ND & ND & 0.0081 & ND & ND & 0.1 & 0.1395 & ND & ND & 0.0119 & ND & ND & 0.15 \\
\hline Fried meat & 0.2073 & 0.0032 & 0.0009 & 0.1414 & 0.0023 & $6.4 E-4$ & 0.36 & 0.4575 & 0.007 & 0.0019 & 0.3121 & 0.005 & 0.0014 & 0.79 \\
\hline Fried chicken & 0.0174 & 0.0034 & ND & 0.0799 & 0.0004 & $2.3 E-4$ & 0.1 & 0.0385 & 0.0076 & ND & 0.1765 & 0.0008 & 0.0005 & 0.22 \\
\hline Fried turkey & 0.0928 & 0.0026 & 0.0026 & 0.0753 & 0.0002 & $4.6 E-4$ & 0.17 & 0.2049 & 0.0058 & 0.0058 & 0.1663 & 0.0005 & 0.001 & 0.38 \\
\hline $\begin{array}{l}\text { Edible maggot } \\
\text { Umunede }\end{array}$ & 0.0092 & 0.0029 & ND & 0.0192 & 0.0006 & $1.9 E-3$ & 0.03 & 0.0181 & 0.0057 & ND & 0.0378 & 0.0012 & 0.0039 & 0.07 \\
\hline Fried fish & 0.0689 & 0.0031 & 0.0053 & 0.07 & 0.0003 & $1.3 E-3$ & 0.15 & 0.1135 & 0.0022 & 0.0087 & 0.1154 & 0.0005 & 0.0021 & 0.24 \\
\hline Stewed meat & 0.8871 & 0.0045 & 0.0123 & 0.0139 & 0.0008 & $4.1 E-3$ & 0.92 & 1.9581 & 0.0099 & 0.0272 & 0.0306 & 0.0018 & 0.009 & 2.04 \\
\hline Roasted plantain & 0.2233 & ND & ND & 0.015 & ND & $3.0 E-4$ & 0.24 & 0.2079 & ND & ND & 0.014 & ND & 0.0003 & 0.22 \\
\hline Roasted yam & 0.0909 & ND & ND & 0.0093 & ND & $9.0 E-4$ & 0.1 & 0.0848 & ND & ND & 0.0087 & ND & 0.0008 & 0.09 \\
\hline Spaghetti & 0.3033 & ND & ND & ND & ND & $5.0 E-4$ & 0.3 & 0.5079 & ND & ND & ND & ND & 0.0008 & 0.51 \\
\hline White rice & 1.2908 & ND & ND & 0.1425 & ND & $1.0 E-4$ & 1.43 & 2.162 & ND & ND & 0.2387 & ND & 0.0002 & 2.4 \\
\hline Beans & 1.7143 & ND & ND & 0.0175 & ND & $1.5 E-3$ & 1.73 & 2.8714 & ND & ND & 0.0293 & ND & 0.0025 & 2.9 \\
\hline Buns & 0.0976 & ND & ND & ND & ND & $4.0 E-4$ & 0.09 & 0.1423 & ND & ND & ND & ND & 0.0006 & 0.14 \\
\hline Moi-moi & 1.5459 & ND & ND & ND & ND & $4.0 E-4$ & 1.55 & 2.5893 & ND & ND & ND & ND & 0.0006 & 2.59 \\
\hline Fried plantain & 0.1694 & ND & ND & 0.0164 & ND & $2.0 E-4$ & 0.19 & 0.1581 & ND & ND & 0.0153 & ND & 0.0002 & 0.17 \\
\hline
\end{tabular}

$\mathrm{ND}=$ not detected.

children. Stewed meat with an intake rate of $3.7 E-6$ and $8.17 E-6$ for both adults and children contributed the highest daily intake of $\mathrm{Hg}$. Also the consumption of fried meat and white rice with an EDI of $5.70 E-6$ was observed to be the source for highest intake of $\mathrm{Sb}$ in adults while the highest intake of $\mathrm{Sb}$ for children was seen in fried meat $(1.20 E-4)$. The EDI of Mn from street food samples ranged within 9.2E$6-5.7 E-4 \mathrm{mg} / \mathrm{kg}$ bw/day in adults and $1.3 E-5-1.3 E-3 \mathrm{mg} / \mathrm{kg}$ bw/day in children; the highest value was found in stewed meat for both adults and children with intake values of 5.7E-4 and $1.3 E-3 \mathrm{mg} / \mathrm{kg}$ bw/day, respectively.

The target hazard quotient (THQ) of each metal through consumption of street foods sold in the vicinity of Benin for both adults and children increased in the following order: $\mathrm{Al}<\mathrm{Mn}<\mathrm{Hg}<\mathrm{Cd}<\mathrm{Sb}<\mathrm{Pb}$, as shown in Table 3 . The maximum value of THQ was seen in jollof rice $(0.39$ and 0.65 ) for adults and children in $\mathrm{Pb}$. The THQ values of other street foods varied from $\mathrm{Pb}(0.0092-0.3896), \mathrm{Cd}$ (0.0026-0.0034), Hg (0.0009-0.0026), Sb (0.0081-0.1414), $\mathrm{Mn}(0.0002-0.0023)$, and $\mathrm{Al}(6.6 E-5-1.9 E-3)$, respectively, for adults and also for children ranged from $\mathrm{Pb}$ (0.0181-0.6526), Cd (0.0057-0.0076), Hg (0.0019-0.0058), Mn (0.0110-0.3121), Sb (0.0008-0.0029), and Al (0.0001$0.0039)$, respectively. The THQ values for street food consumption from Benin City were less than 1. The THQ of heavy metals from street food in Umunede increased in the following order: $\mathrm{Mn}<\mathrm{Al}<\mathrm{Cd}<\mathrm{Hg}<\mathrm{Sb}$ and $\mathrm{Pb}$, with values ranging between $\mathrm{Pb}(0.0689-1.7143), \mathrm{Cd}(0.0031-0.0045), \mathrm{Hg}$ (0.0053-0.0123), Sb (0.0093-0.1425), Mn (0.0003-0.0008), and $\mathrm{Al}(0.0001-0.0041)$, respectively, for adults and ranging from $\mathrm{Pb}(0.0848-2.8714), \mathrm{Cd}(0.0002-0.0099), \mathrm{Hg}$ (0.0087-0.02720), Sb (0.0087-0.2387), Mn (0.0005-0.0018), and $\mathrm{Al}$ (0.0002-0.0025), respectively, for children. THQ values for $\mathrm{Pb}$ in street foods beans (1.7143), white rice (1.2908), and moi-moi (1.5459) for adults and $\mathrm{Pb}$ THQ values for beans (2.8714), white rice (2.162), moi-moi (2.5893), and stewed meat (1.9581) for children were higher than 1 .

Table 3 also shows the hazard index of mixtures of metal intake from street food for adults and children. In children the HI value was highest in beans (2.9) and least in roasted yam (0.09) while for adults HI value was highest in beans (1.73) and least in buns (0.09) as seen in Table 3.

\section{Discussion}

Heavy metals are considered as one of the most important constituents of food contamination from the environment due to its ability to persist, accumulate, and become toxic to living organism through consumption [17]. This present study is a risk assessment study of lead $(\mathrm{Pb})$, cadmium (Cd), mercury ( $\mathrm{Hg})$, antimony ( $\mathrm{Sb})$, manganese $(\mathrm{Mn})$, and aluminium (Al) in different street-vended foods sold in Benin City and Umunede of Mid-Western Nigeria; the trend of heavy metals contamination in the street food sample decreased in the following order: $\mathrm{Pb}>\mathrm{Al}>\mathrm{Sb}>\mathrm{Mn}>\mathrm{Cd}$ $>\mathrm{Hg}$.

Lead was detected in all the street food samples, with $100 \%$ of street food samples seen to be higher than $0.01 \mathrm{mg} / \mathrm{kg}$ 
which is the maximum permissible limit set by WHO/FAO and also the maximum allowable concentration of $0.02 \mathrm{mg} / \mathrm{kg}$ by EU and $0.05 \mathrm{mg} / \mathrm{kg}$ limit set by USEPA; Pb levels were also in violation of these standards except for fried chicken and edible maggot which were below $0.05 \mathrm{mg} / \mathrm{kg}$ and therefore within the acceptable limit. The high percentage of food samples which were in violation of the maximum permissible limits of $\mathrm{Pb}$ set by WHO, EU, and US EPA is a cause for public health concern considering the frequency of exposure. The consumption of food contaminated with $\mathrm{Pb}$ is the major source of exposure to $\mathrm{Pb}$ in a general population [18].

These values were higher than the $\mathrm{Pb}$ values reported by Bordajandi et al. [19] in food samples from Huelva (Spain). High concentration burden of $\mathrm{Pb}$ in the body can cause irreversible brain damage (encephalopathy), anemia, coma, and death if not treated immediately [20]. Long-term system exposure can cause damage to the kidneys and reproductive and immune system. Children are more vulnerable than adults to the toxic effects of $\mathrm{Pb}$ and they also absorb $\mathrm{Pb}$ easily. A low blood lead level can affect the intellectual development or IQ of young children [21]. Cadmium is classified by the IARC as a group 1 cancer causing agent. It has been shown that chronic exposure to low doses of cancer causing heavy metals may be implicated in various types of cancer. In the current study, the levels of cadmium detected in street food samples were all below the permissible limit of Cd set by US $\mathrm{EPA}, \mathrm{WHO}$, and EU $(0.05 \mathrm{mg} / \mathrm{kg})$. Although most samples contaminated with $\mathrm{Cd}$ were below the detectable limit, $\mathrm{Cd}$ was detected in $30 \%$ of the street food samples which were mainly meat based food products such as fried meat, fried chicken, fried turkey, edible maggot, and stewed meat. With a half-life of 10 years, this trend of Cd contamination on mostly meat samples could be as a result of bioaccumulation of $\mathrm{Cd}$ in the animals. Dietary Cd intake due to the consumption of environmentally contaminated rice and other foods was associated with an increased risk of postmenopausal breast cancer [14]. Mercury showed the least level of contamination in street foods, detected in $20 \%$ of the samples ranging between 0.0003 and 0.0014 in predominantly meat based food products which include stewed meat, fried meat, fried fish, and fried turkey. The concentration of $\mathrm{Hg}$ in street food samples was below the food safety limits. Inorganic mercury in aquatic environment is transformed by microorganism into methyl mercury which is lipophilic and biomagnify in the food chain. Mothers who are exposed to Hg through their diet pass the toxicant to their fetus and to infants through breast milk [22]. This makes the fetus and children more vulnerable to low level mercury leading to toxicity. Decreased performance in area of motor functions and memory loss has been reported among children exposed to presumably safe mercury level. Similarly, disruption of attention, fine motor function, and verbal memory was also found in adult on exposure to low mercury level [23]. Mercury has been found to be a causative agent of various sorts of disorders, including neurological [24], renal [25], reproduction [26], genetic [27], cardiac [28], and immunological [29] disorders.

Manganese is an essential trace metal for animal with essential enzymes activities in the biochemical processes of the body. However, in large quantities the metal can cause acute and chronic poisoning. Manganese was detected in 35\% of street food samples with concentrations ranging between 0.0011 and $0.01 \mathrm{mg} / \mathrm{kg}$ which is lower than the guideline value of $0.16 \mathrm{mg} / \mathrm{kg}$ [30]. Mn can be neurotoxic when exceeding the homeostatic range [31]. Mn exposure is associated with cognitive, motor, and behavior deficits in children.

Aluminium $(\mathrm{Al})$ and antimony $(\mathrm{Sb})$ are also among the potential toxic metals that have no biological function in the body. $\mathrm{Al}$ and $\mathrm{Sb}$ are considerably less toxic than either $\mathrm{Hg}$ or $\mathrm{Pb}$ but can be toxic at higher levels. In this study $\mathrm{Al}$ and $\mathrm{Sb}$ were detected in $90 \%$ and $75 \%$ of the street food samples, respectively; their ranges were $\mathrm{Al}(0.00-0.23 \mathrm{mg} / \mathrm{kg})$ and $\mathrm{Sb}$ $(0.00-0.021) \mathrm{mg} / \mathrm{kg}$. Al and Sb values were below the permissible limit of $1 \mathrm{mg} / \mathrm{kg}$ for both metals (ATSDR 1999). Higher level of $\mathrm{Al}$ has the potential to cause a number of health problems such as neuromuscular disorder, osteomalacia, Parkinson's disease, autism, Alzheimer's disease, and autoimmunity [32]. Antimony toxicity is characterised by gastrointestinal symptoms, vomiting, kidney damage, and so forth [33].

To assess the risk of heavy metal exposure to human health in the exposed population, information about the dietary intake is necessary. Tolerable daily intake (TDI) is an estimate of daily exposure to the human population that is likely to be without an appreciable risk of adverse effect during a life time. In this study the estimated daily intake of $\mathrm{Pb}$ for adult and children was in the range of $0.00004-0.0069 \mathrm{mg} / \mathrm{kg}$ day and $0.000072-0.011 \mathrm{mg} / \mathrm{kg} /$ day, respectively. Some of the street foods were in violation of the tolerable daily intake for a $70 \mathrm{~kg}$ individual and children with a lower body weight which had higher intake of $\mathrm{Pb}$ and this is of health risk concern. Amongst the street foods that violated the tolerable daily intake (TDI) of $\mathrm{Pb}$ for adults and children were stewed meat, white rice, beans, and moimoi. This observation is noteworthy and of significant public health importance in both children and adult since the food items are usually taken together as a meal. Daily intake of these street foods may likely cause significant health hazard to the residents. For the other potential toxic metals such as $\mathrm{Cd}$, $\mathrm{Hg}, \mathrm{Sb}, \mathrm{Mn}$, and $\mathrm{Al}$ their estimated daily intake was below the tolerable daily intake for both adults and children set by FAO, WHO, and US EPA. The calculated THQ values of potential toxic metals for both adult and children in the present study presented a public health concern with THQ values $>1$ in some samples. The THQ of $\mathrm{Pb}$ in white rice, beans, and moimoi were above 1 for adults, while for children stewed meat, white rice, beans, and moi-moi also had values greater than 1 and higher than the values in adults. Children are more susceptible to heavy metal poisoning than adults due to their reduced body weight, hence the reason for increased toxicity. These THQ values are an indication that street food samples which had values $>1$ are unsafe for human consumption. The THQ for $\mathrm{Cd}, \mathrm{Hg}, \mathrm{Sb}, \mathrm{Mn}$, and $\mathrm{Al}$ can be considered to be safe for the consumers due to their low noncarcinogenic risk presenting values $<1$.

Hazard index which was calculated to represent the combined risk of heavy metal toxicity is the sum total of all the THQ values in a food sample and a value $>1$ is an indication that the probability of an adverse health effect associated with 
such exposure is high. For adults the HI value due to the consumption of white rice, beans, and moi-moi was greater than 1 while for children stewed meat, white rice, beans, and moi-moi had a higher HI value when compared to adults. Dietary combinations (jollof rice in combination with salad and fried meat or white rice combined with fried plantain and fried chicken) which are common in Nigeria may increase the exposure risk and possibility of metal toxicity.

Carcinogenic risk is estimated and expressed as a probability of contracting cancer over a lifetime of 70 years. The cancer risk decreased in the order of $\mathrm{Pb}>\mathrm{Cd}$. The total cancer risk for adults and children, respectively, was $5.1 E-05$ and $8.6 E-05$ (Benin City) and 2.2E - 04 and $3.7 E-04$ (Umunede); these ranges were seen to be within the priority risk level of $1.0 E-04$ but higher than the acceptable risk level of $1 E-06$ [34]. This suggests that, for toxic metals $\mathrm{Pb}$ and $\mathrm{Cd}$, the carcinogenic risk through consumption of street foods for both adult and children is of public health concern. The sources of potential toxic metals contamination in these street foods may be at the points of handling and processing/cooking given the heavy vehicular traffic and sundry activities characteristic of these vending areas. The source of the raw food (farm produce and poultry) may be of concern too. Mindful of only making profit, vendors may purchase cheap and substandard, raw foods from unsafe environments (e.g., fish caught in waters where fishing is prohibited and vegetables or rice that are cultivated in heavily polluted soils) [35]. Street foods may also be contaminated by chemical toxicant due to leaching from cooking utensils, roasting gauzes, and packaging materials. Location of street food vendors in congested streets and bus or train stations exposes the food to airborne pollutant deposition from automobile exhaust fumes [36].

\section{Conclusion}

Taken together all the potential toxic metals concentrations and daily intake except $\mathrm{Pb}$ in this study were lower than the limit established by the EU, WHO, and USEPA. The daily intake, THQ, and $\mathrm{HI}$ of $\mathrm{Pb}$ in some street food samples were higher than the established limit, an indication of health risk among the exposed population. Foodstuffs contamination by heavy metals is unavoidable as a result of their presence in the environment (air, water, and soil) and this can be detrimental to human health due to their ability to accumulate in body tissues.

\section{Conflicts of Interest}

The authors declare that there are no conflicts of interest regarding the publication of this paper.

\section{References}

[1] WHO, Essential Safety Requirements for Street-vended Foods, Revised Edition, Food Safety Unit, World Health Organization, Geneva, Switzerland, 1996.

[2] A. M. Mwangi, A. P. den Hartog, D. W. J. Foeken, H. van't Riet, R. K. N. Mwadime, and W. A. van Staveren, "The ecology of street foods in Nairobi," Ecology of Food and Nutrition, vol. 40, no. 5, pp. 497-523, 2001.

[3] FAO, Promises and Challenges of the Informal Food Sector in Developing Countries, FAO, Rome, Italy, 2007.

[4] O. Ohiokpehai, "Nutritional aspects of street foods in Botswana," Pakistan Journal of Nutrition, vol. 2, no. 2, pp. 76-81, 2003.

[5] I. Tinker, "Street foods: traditional micro-enterprise in a modernizing world," International Journal of Politics, Culture and Society, vol. 16, no. 3, pp. 331-349, 2003.

[6] S. Rane, "Street vended food in developing world: hazard analyses," Indian Journal of Microbiology, vol. 51, no. 1, pp. 100106, 2011.

[7] A. M. Omemu and S. T. Aderoju, "Food safety knowledge and practices of street food vendors in the city of Abeokuta, Nigeria," Food Control, vol. 19, no. 4, pp. 396-402, 2008.

[8] O. E. Orisakwe, H. O. C. Mbagwu, G. C. Ajaezi, U. W. Edet, and P. U. Uwana, "Heavy metals in seafood and farm produce from Uyo, Nigeria: levels and health implications," Sultan Qaboos University Medical Journal, vol. 15, no. 2, pp. e275-e282, 2015.

[9] O. E. Orisakwe, J. K. Nduka, C. N. Amadi, D. O. Dike, and O. Bede, "Heavy metals health risk assessment for population via consumption of food crops and fruits in Owerri, South Eastern, Nigeria," Chemistry Central Journal, vol. 6, article 77, 2012.

[10] M. Arora, B. Kiran, S. Rani, A. Rani, B. Kaur, and N. Mittal, "Heavy metal accumulation in vegetables irrigated with water from different sources," Food Chemistry, vol. 111, no. 4, pp. 811$815,2008$.

[11] N. Zheng, Q. Wang, X. Zhang, D. Zheng, Z. Zhang, and S. Zhang, "Population health risk due to dietary intake of heavy metals in the industrial area of Huludao city, China," Science of the Total Environment, vol. 387, no. 1-3, pp. 96-104, 2007.

[12] J. G. Farmer, A. Broadway, M. R. Cave et al., "A lead isotopic study of the human bioaccessibility of lead in urban soils from Glasgow, Scotland," Science of the Total Environment, vol. 409, no. 23, pp. 4958-4965, 2011.

[13] USEPA, "Supplementary guidance for conducting health risk assessment of chemical mixtures," Risk Assessment Forum Technical Panel EPA/630/R-00/002, USEPA, Washington, DC, USA, 2000.

[14] H. Itoh, M. Iwasaki, N. Sawada et al., "Dietary cadmium intake and breast cancer risk in Japanese women: a case-control study," International Journal of Hygiene and Environmental Health, vol. 217, no. 1, pp. 70-77, 2014.

[15] A. Singh, R. K. Sharma, M. Agrawal, and F. M. Marshall, "Risk assessment of heavy metal toxicity through contaminated vegetables from waste water irrigated area of Varanasi, India," Tropical Ecology, vol. 51, no. 2, pp. 375-387, 2010.

[16] US Environmental Protection Agency (USEPA), "Region 9, preliminary remediation goals," 2002, http://waste.ky.gov/sfb/documents/region9prgs.pdf.

[17] S. Díez, S. Delgado, I. Aguilera et al., "Prenatal and early childhood exposure to mercury and methylmercury in spain, a high-fish-consumer country," Archives of Environmental Contamination and Toxicology, vol. 56, no. 3, pp. 615-622, 2009.

[18] FSA, Mercury, Lead, Cadmium, Tin and Arsenic in Food, Toxicology Factsheet Series., The Food Safety Authority of Ireland, Dublin, Ireland, 2009.

[19] L. R. Bordajandi, G. Gómez, E. Abad et al., "Survey of persistent organochlorine contaminants (PCBs, PCDD/Fs, and PAHs), heavy metals $(\mathrm{Cu}, \mathrm{Cd}, \mathrm{Zn}, \mathrm{Pb}$, and $\mathrm{Hg})$, and arsenic in food 
samples from Huelva (Spain): levels and health implications," Journal of Agricultural and Food Chemistry, vol. 52, no. 4, pp. 992-1001, 2004.

[20] S. Vijayakumar, M. Sasikala, and R. Ramesh, "Lead poisoningan overveiw," International Journal of Pharmacology \& Toxicology, vol. 2, no. 2, pp. 70-82, 2012.

[21] Agency for Toxic Substances and Disease Registry (ATSDR): Toxicological Profile for Lead, Department of Health and Human Services, Public Health Service, Atlanta, Ga, USA, 2007.

[22] P. Grandjean, P. Weihe, and R. F. White, "Milestone development in infants exposed to methylmercury from human milk," NeuroToxicology, vol. 16, no. 1, pp. 27-34, 1995.

[23] F. Zahir, S. J. Rizwi, S. K. Haq, and R. H. Khan, "Low dose mercury toxicity and human health," Environmental Toxicology and Pharmacology, vol. 20, no. 2, pp. 351-360, 2005.

[24] P. N. T. Johnson and R. M. Yawson, "Enhancing the food security of the peri urban and urban poor through improvements to the quality, safety and economics of street-vended foods," in Proceedings of the Workshop for Stakeholders, Policy Makers and Regulators of Street-food Vending in Accra, DFID/NRI/FRI Crop Post Harvest Program Project, Accra, Ghana, September 2000.

[25] F. J. Dieguez-Acuña, W. W. Polk, M. E. Ellis, P. L. Simmonds, J. V. Kushleika, and J. S. Woods, "Nuclear factor $\kappa \mathrm{B}$ activity determines the sensitivity of kidney epithelial cells to apoptosis: implications for mercury-induced renal failure," Toxicological Sciences, vol. 82, no. 1, pp. 114-123, 2004.

[26] H. A. Anderson, L. P. Hanrahan, A. A. Smith, L. Draheim, M. Kanarek, and J. Olsen, "The role of sport-fish consumption advisories in mercury risk communication: a 1998-1999 12-state survey of women age 18-45," Environmental Research, vol. 95, no. 3, pp. 315-324, 2004.

[27] M. V. Rao, N. J. Chinoy, M. B. Suthar, and M. I. Rajvanshi, "Role of ascorbic acid on mercuric chloride-induced genotoxicity in human blood cultures," Toxicology in Vitro, vol. 15, no. 6, pp. 649-654, 2001.

[28] H. M. Chan and G. M. Egeland, "Fish consumption, mercury exposure, and heart diseases," Nutrition Reviews, vol. 62, no. 2, pp. 68-72, 2004.

[29] C. A. Hudson, L. Cao, J. Kasten-Jolly, J. N. Kirkwood, and D. A. Lawrence, "Susceptibility of lupus-prone NZM mouse strains to lead exacerbation of systemic lupus erythematosus symptoms," Journal of Toxicology and Environmental Health Part A, vol. 66, no. 10, pp. 895-918, 2003.

[30] FNB/IOM, "Manganese. Dietary reference intakes for vitamin A, vitamin $\mathrm{K}$, arsenic, boron, chromium, copper, iodine, iron, manganese, molybdenum, nickel, silicon, vanadium, and zinc (2000)," in A Report of the Panel on Micronutrients, Subcommittees on Upper Reference Levels of Nutrients and of Interpretation and Uses of Dietary Reference Intakes, and the Standing Committee on the Scientific Evaluation of Dietary Reference Intakes, pp. 394-419, Food and Nutrition Board. Institute of Medicine National Academy Press, Washington, DC, USA, 2001.

[31] R. G. Lucchini, S. Zoni, S. Guazzetti et al., "Inverse association of intellectual function with very low blood lead but not with manganese exposure in Italian adolescents," Environmental Research, vol. 118, pp. 65-71, 2012.

[32] C. A. Shaw and L. Tomljenovic, "Aluminum in the central nervous system (CNS): toxicity in humans and animals, vaccine adjuvants, and autoimmunity," Immunologic Research, vol. 56, no. 2-3, pp. 304-316, 2013.
[33] S. Sundar and J. Chakravarty, "A review on antimony toxicity," International Journal of Environmental Research and Public Health, vol. 7, no. 12, pp. 4267-4277, 2010.

[34] Z. H. Xia, X. L. Duan, W. X. Qiu et al., "Health risk assessment on dietary exposure to polycyclic aromatic hydrocarbons (PAHs) in Taiyuan, China," Science of the Total Environment, vol. 408, no. 22, pp. 5331-5337, 2010.

[35] I. Proietti, C. Frazzoli, and A. Mantovani, "Identification and management of toxicological hazards of street foods in developing countries," Food and Chemical Toxicology, vol. 63, pp. 143152, 2014.

[36] A. P. Simopoulos and R. V. Bath, "Street foods," World Review of Nutrition and Dietetics, vol. 86, pp. 53-99, 2000. 


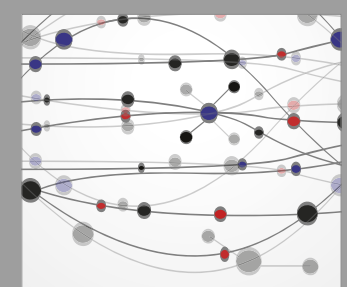

The Scientific World Journal
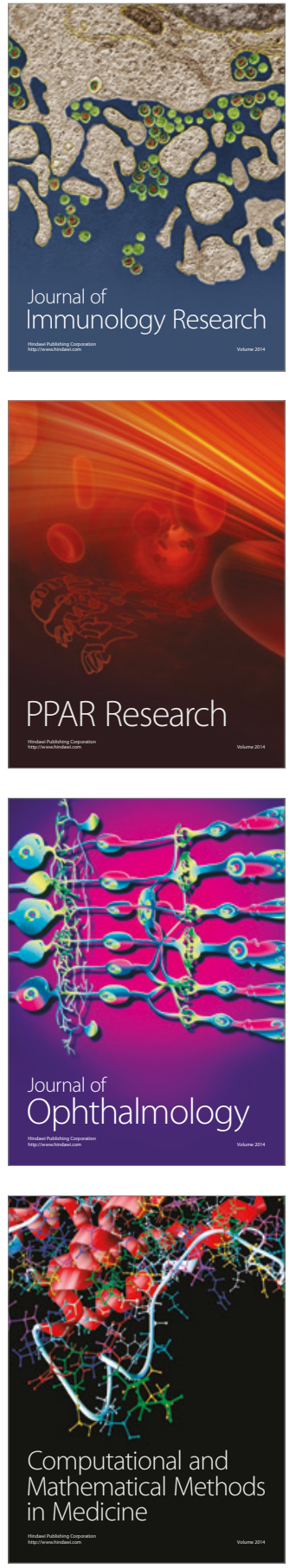

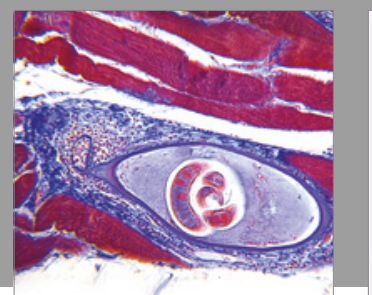

Gastroenterology Research and Practice
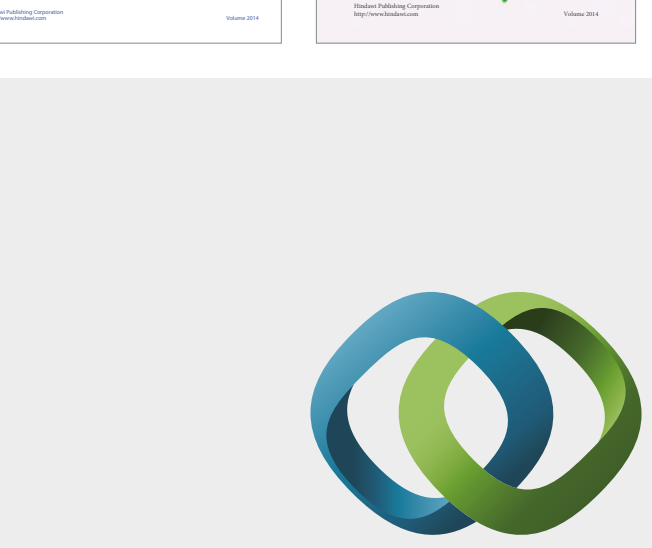

\section{Hindawi}

Submit your manuscripts at

https://www.hindawi.com
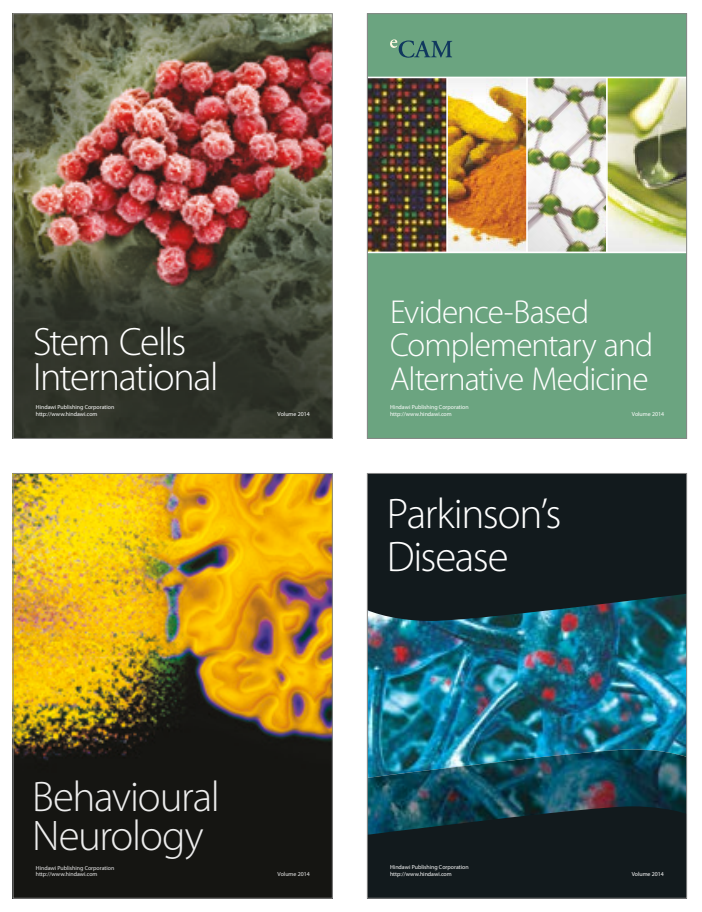
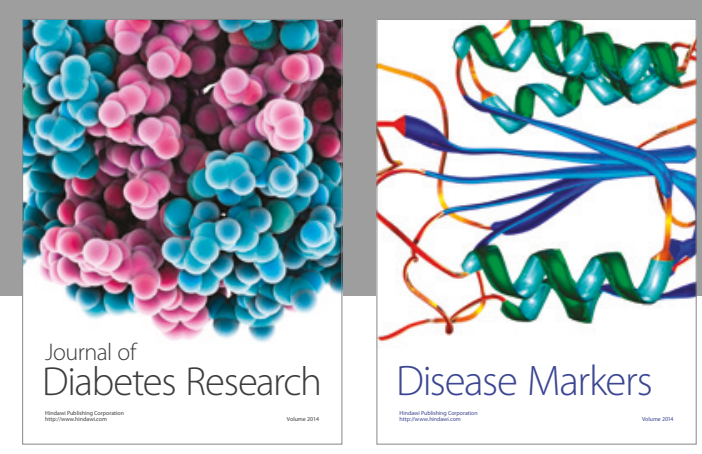

Disease Markers
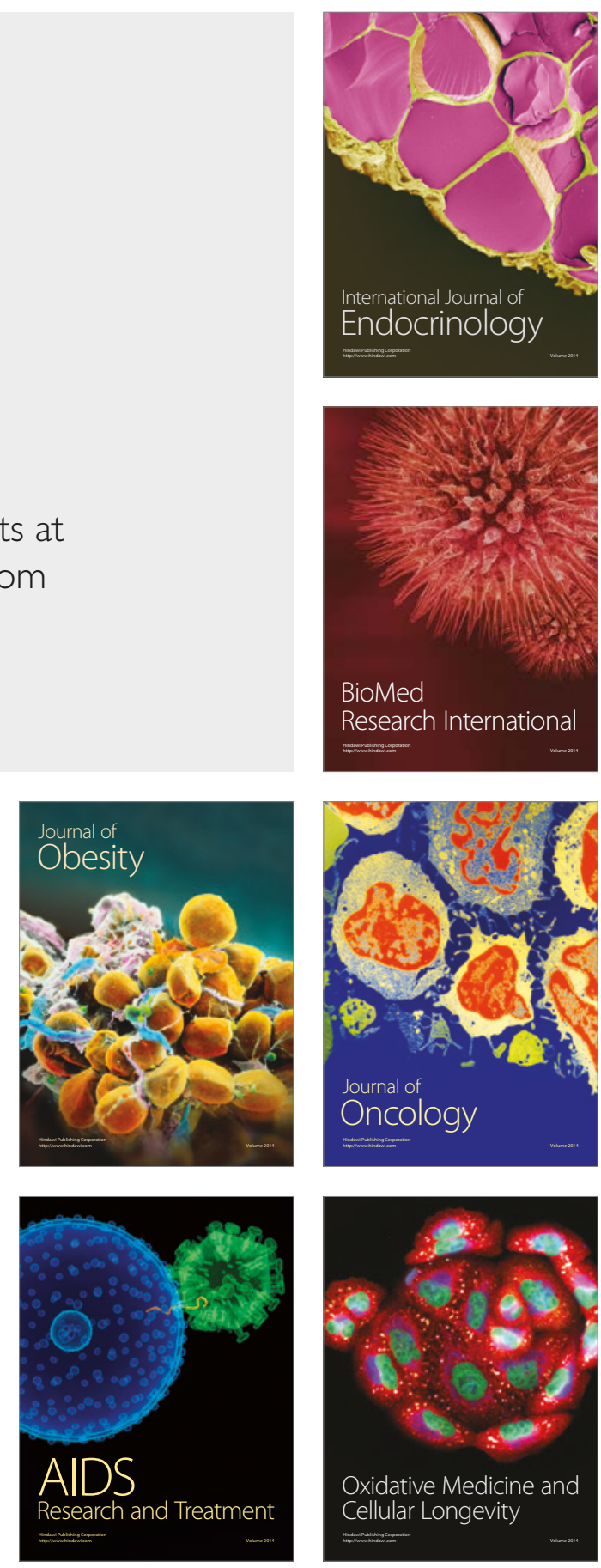